\title{
11 Beveridge or Bismarck? Choosing the Nordic model in British healthcare policy 1997-c.2015
}

\author{
Tom Hoctor
}

\section{Introduction}

Historical and social science literature has a long tradition of interest in the Nordic model and its permutations and developments (Logue, 1999; Einhorn and Logue, 2003; Scott, 2009). Necessarily, there has been a political dimension to this interest, both in Norden and outside it. The primary aim of this chapter is to consider interest in the Nordic countries among British policymakers in the field of healthcare from 1997 to 2010. British political interest in the Nordic model has historically been highest among social democrats and socialists; however, there is evidence that Nordic ideas appeal beyond their traditional centres, with novel (at least in British terms) ideas about the Scandinavian social systems taking hold from the late-1990s onwards.

This chapter will make two straightforward and related claims. First, that ideas about the Nordic model circulated in British political circles in the period 1997-2010, and second, that this Nordic model was a departure from the 'traditional' social democratic conception of Norden (Ryner, 2002, 2007; Andersson, 2009b, 2010). Instead, in this era, the Nordic model was more often associated with New Public Management policies. To substantiate this claim, I will use a policy diffusion model and data drawn from political speeches, think-tank pamphlets and the business and popular presses. It, therefore, fits into a growing qualitative literature on international policy diffusion (Starke, 2013).

\section{Policy and institutional context}

\section{New Public Management and policy diffusion}

This section will discuss the contemporary literature in the fields of New Public Management and policy diffusion and discuss how these concepts can be used to frame the transfer of policies between the Nordic countries and the United Kingdom.

An increasingly large literature has developed on policy diffusion in political and social science. The Nordic countries, especially Sweden, have long 
served as international policy models in a variety of contexts (Musial, 2000; Hilson and Newby, 2015). Marklund (2009) notes that by the 1930s Sweden had increasingly come to be seen as a 'social laboratory', and though interest in the Nordic countries in the United Kingdom as well as the rest of the Anglophone world has waxed and waned over time, there are commonalities in the characteristics assigned to the Nordic social systems.

In the 1950s and 1960s, interest in the Nordic countries was centred on their perceived conformity to social democratic principles. Sweden has a significant place in Anthony Crosland's ([1956] 1980) The Future of Socialism and a refutation of Sweden's utopian socialist status is the central argument of Perry Anderson's (1961a, 1961b) responses in New Left Review, the first of which is acerbically titled 'Mr Crosland's Dreamland' (Hale, 2009). Roland Huntford's (1971) The New Totalitarians added a conservative counterview to the idea of utopian Sweden (Hale, 2006). Despite their ethical disagreements, these authors were broadly in agreement about the social democratic character of Swedish society, and this rather unproblematised view has tended to extend to the other four Nordic countries, whether or not it is strictly historically accurate (Kettunen, 2012). What can be said is that the 'Nordic model' has circulated in British political discourse for a very significant period of time, usually in circles associated with the Labour Party and typically associated with arguments about gradualism (Aimer, 1985).

The 2000s, therefore, present a novel image of the Nordic model, which instead of association with solidaristic wage policies, collective bargaining and social welfare are associated with New Public Management (NPM). NPM policies have several key characteristics:

1 The introduction or extension of markets into public goods and spheres of social value (Self, 1993)

2 'Structural devolution' (Christensen and Lægreid, 2007: 102), entailing the creation of new agencies and regulatory bodies, often outside direct democratic control

3 The possible privatisation of public service provision and/or funding (Krachler and Greer, 2015)

NPM policies have circulated in Western Europe since the 1970s and have been associated with wider reform trends under the gloss of 'globalisation' and 'neoliberalism' in the past 50 years (Ryner, 2002; Einhorn and Logue 2003; Brown, 2015).

Christensen, Lie and Lægreid (2007) note that marketising reform is often accompanied by the creation of myths and symbols. Political science scholars interested in the diffusion of policy across national borders also stress the importance of legitimacy to the adoption of a policy. Maggetti and Gilardi (2016: 87), for example, note that 'a policy model can be adopted because it is highly valued by peers, provides legitimacy to adopters or is widely accepted as an appropriate response to a given problem'. The use of 
Nordic examples to accompany NPM reform under New Labour is a useful empirical example of the efficacy of symbols and their role in providing political legitimacy in the creation of public policy.

Moreover, it is clear that part of the reason for the adoption of a Nordic model by Labour reflects the requirement for 'ideological similarity' when selecting an appropriate policy model (Grossback et al., 2004: 522). Since the 1990s and throughout the period considered here, this 'ideological similarity' was clearly felt in both directions, since 'New Public Management reforms were implemented in most western countries, and Swedish health care politicians tended to look to Great Britain for inspiration when implementing them at home' (Blomgren and Sahlin, 2007: 163). In a sense, therefore, though British politicians were allegedly looking abroad at the Nordic countries to supply ideas about health reforms, politicians elsewhere were looking to Britain as a site of policy learning.

It is worth noting that very often in policy diffusion 'the weight of new information depends on prior beliefs' (Gilardi, 2010: 652). As will be demonstrated below, there was a common belief in the United Kingdom that there were ideological commonalities between reform trajectories in both regions and prior beliefs about the Nordic model, dating as far back as the 1960s, were clearly important to the willingness of UK politicians to look to the Nordic region for legitimacy. Though it exceeds the scope of this chapter, this process of mutual circulation is clearly worthy of further study.

A similar diffusion process was being undertaken by British critics of the National Health Service (NHS). Generally associated with the Conservative Party, these critics were often in agreement with elements of the marketisation aspects of the NPM reform trajectory but wished to see the United Kingdom's health system shift to an insurance-funded, rather than a taxation-funded model. The Nordic model was, therefore, not suitable for these purposes, and instead, these policymakers looked to the Social Health Insurance (SHI) systems of Central Europe for policy learning. As will be shown below, the strategies of critics of general taxation funded healthcare, though similar to those pursued by Labour, were different in important ways, even if they relied on similar legitimacy claims.

NHS reform from the late 1980s conforms to the general move away from corporatist steering mechanisms towards lobbying - a trend which is also evident in the Nordic countries (Rommetvedt, 2017). In its place, a system emerged based on looser affiliation between actors. Though this term is often used negatively, at least in Britain, here it will be used descriptively, in the sense in which Rommetvedt deploys it, to explain the replacement of institutionalised two-way relationships between government and nongovernmental actors with more informal one-way relationships, in which governments are lobbied to advance single issue causes. For present purposes, the implications of the move away from corporatist management of the NHS can be considered quite narrowly, since the primary goal is to explain the behaviour of actors in the policy creation process. 
One of the most significant innovations of the Thatcher-era was the role of think tanks as sources of public policy (Jackson, 2012). This was substantially retained under New Labour with the growth of social democratic counterparts to the Institute of Economic Affairs (IEA), Centre for Policy Studies (CPS) and Adam Smith Institute (ASI) which had been active under the Thatcher and Major governments. Think tanks which influenced Labour policy included the Institute for Public Policy Research (IPPR), Policy Network as well as centrist liberal organisations such as Civitas and the Social Market Foundation (SMF).

Think tanks provided Labour with new ideas and organised international connections. Policy Network, for example, has been chaired by Peter Mandelson, a key architect of the transformation to New Labour. Among its high-profile Nordic contributors is Helle Thorning-Schmidt, former Prime Minister of Denmark. Pär Nuder, a former Swedish Social Democratic Finance Minister, has contributed several publications to the IPPR (Nuder, 2002, 2012). There were also connections during this era between members of the Swedish Moderate Party and the free-market IEA. Johan Wennström, formerly of Timbro, a Stockholm-based free-market think tank, and later an adviser to the second Reinfeldt government, was a fellow at the IEA in 2005 (Wennström, 2005).

This institutional inheritance was a double-edged sword for Labour. Although think tanks conformed to the post-ideological, pragmatic focus of the Third Way project (Ball and Exley, 2010), in common with other elements of NPM, they were also less amenable to steering than traditional policy creation and implementation partners such as trade unions and professional associations (Christensen and Lægreid, 2002). New Labour's desire to maintain broad-based support, including among traditionally hostile groups like free-market think tanks and conservative newspapers, empowered these groups to mount challenges to Labour's articulations of the NHS and to provide alternative policy models. For this reason, although less influential than they had been under the previous Conservative governments, free-market articulations of healthcare policy, especially regarding SHI, remained influential and problematic for Labour politicians.

\section{Healthcare policy in Norden, Germany and the United Kingdom}

This chapter will cover a diverse range of national and regional policies. It is, therefore, worth sketching out the basic contours of the United Kingdom, Nordic and 'Bismarckian' healthcare systems while emphasising that the purpose of this paper is not to comment on the empirical merits of any of these systems, but, rather, to explore how they were presented by British political actors as cases for reform. It is, therefore, principally a study of the ways in which Nordic policy ideas were translated into the context of the United Kingdom. 
The Nordic healthcare regimes have undergone significant change in the past 20-30 years. As noted above, each of them has been affected by reform processes, which were to greater or lesser degrees influenced by NPM, but in different ways in different periods. The Nordic countries are sometimes, though less often in the last two decades, classified as members of a 'reluctant reformer' group, of which some continental states are also considered a part (Christensen and Lægreid, 2002; Christensen et al., 2007; Bjurstrøm and Christensen, 2017). This has been reflected in healthcare with the five Nordic countries moving from different starting points at different speeds and in somewhat different directions. What unites them is their continued use of a general taxation funded-model (Lyttkens et al., 2016).

From a British perspective, the Nordic countries share underlying principles with the NHS but operate in a far more decentralised fashion and with a significantly greater emphasis on democratic participation (Magnussen and Martinussen, 2013). This decentralisation makes a comprehensive description of the Nordic healthcare systems difficult (Lyttkens et al., 2016), though it is nonetheless reasonable to speak of a Nordic model of healthcare (Martinussen and Magnussen, 2009; Magnussen and Martinussen, 2013; Lyttkens et al., 2016), and certainly the perception in the United Kingdom in the 2000s was that such a thing existed and was a meaningful source of policy learning. I will therefore sketch out the aspects of the Nordic healthcare systems which were most important from the perspective of British health policymakers.

As noted, the Nordic healthcare systems are particularly characterised by decentralisation and democratisation, partly as a result of their less coordinated development by comparison with the NHS. Moreover, the Nordic systems have tended to operate political, administrative and economic decentralisation (Byrkjeflot and Neby, 2008), with a much greater capacity for local raising of funds through taxation compared to Britain's centrally funded system as well as stronger local democratic oversight through local councils (Magnussen and Martinussen, 2013). They nonetheless underwent significant changes during the period under consideration (Christensen and Lægreid, 2002; Bjurstrøm and Christensen, 2017; Christensen et al., 2007).

For present purposes, three changes are of importance: processes of centralisation and decentralisation; purchasing and provision responsibilities and gatekeeping. Recent reform trajectories have tended to entail phases of de- and re-centralisation. The 2000 s coincided with a period of centralisation, in which traditional county and municipal systems of provision were consolidated into larger regions in Denmark and Norway, with Sweden keeping its decentralised structure but allowing greater local experimentation than previously (Byrkjeflot and Neby, 2008).

Because of the tendency to decentralisation, there is significant variety in the extent to which markets and private provision were extended in Nordic healthcare both within and between nation states. Denmark has been the most reluctant to split purchasing and provision, with only very limited 
moves in this direction; Norway provided some secondary care through purchasing mechanisms in the 2000s, and Sweden's decentralised model meant that some counties had significant extension of market mechanisms and private provision, while others had virtually none (Magnussen and Martinussen, 2013). A further difference is in accessibility. In Denmark and Norway, General Practitioners (GPs) function as gatekeepers to the wider system, whereas in Finland any doctor can refer and in Sweden patients are able to self-refer (Olsen et al., 2016). Gatekeeping is also an accepted part of the structure of UK healthcare (Greenfield et al., 2016).

Despite these variations, for the purposes of this chapter, the Nordic systems will be considered part of a 'Beveridgian' type along with the NHS, while the Central European systems will be considered Bismarckian. The paradigmatic Bismarckian system, as the name suggests, is Germany. This is the system that was primarily used as a source of policy learning by those interested in SHI systems in UK politics. In common with most other Western European healthcare systems, the German healthcare system is based on mandatory health insurance with contributions raised from insurance fund members, employers and the state. In other respects, the Bismarckian and Beveridgian systems have converged significantly since the turn of the twenty-first century partly since both systems confronted similar challenges: expanding demand for care; aging populations; rising health complaints associated with poor lifestyles, etc. (Palier and Martin, 2008; Hinrichs, 2010; Palier, 2010).

The priority for Beveridgian systems in the 2000s was to rectify poor accessibility to specialist care through reforms to the GP gatekeeping system. Historically, this was a strength of the Bismarckian systems due to the relative ease of accessing a GP and a referral to a specialist. Conversely, cost containment became a priority for Bismarckian systems, which consolidated state authority over some aspects of the social insurance systems to ease budgetary pressures. Beveridgian systems, due to their tax-funded models (whether local, regional or central), have tended to perform better against cost-containment measures than insurance-based systems.

Historically, the NHS was thought of as a command-and-control structure although arguably this overstates the ability of the Ministry of Health to steer healthcare and understates the abilities of groups, especially the British Medical Council, to resist or subvert central steering mechanisms (Greener and Powell, 2008). UK healthcare reform has taken more than one direction since the beginning of the Thatcher era in 1979. The 1983 Griffiths Report suggested a direction for the NHS which was highly professionalised with doctors and healthcare professionals controlling the administrative aspects of the health service, much like the system which evolved in Scotland in the 2000s (Greer, 2004). This path was abandoned in 1987 with the introduction of the 'internal market' which was the first move towards NPM in British healthcare and introduced a purchaser-provider split, characterised by contracting between independent, but state-funded health authorities, GP fundholding groups and NHS hospital trusts (Greener, 2009). 
The architecture of this system was complex with significant unevenness between the size and autonomy of different purchasers. Indeed, built into the system were significant pressures on larger health authorities to remain with current providers because of the risk that sudden withdrawal would cause them to go bust. These pressures did not affect smaller GP fundholding groups. Moreover, as there had been no increase in care supply and no differential pricing of services was permitted, there was always a route back into public ownership for bankrupt purchasers and providers, rendering the competitive elements of the internal market theoretical (Greener and Powell, 2008).

New Labour instituted a series of strategic health authorities which purchased care from Primary Care Trusts. These covered quite significant geographical areas, for example, the north-west of England, and are reminiscent of the basic division of Norwegian health provision into five regional health authorities. Even though during the New Labour era the British healthcare system most closely resembled that of Norway, this was not mirrored by a focus on the Norwegian healthcare system among policymakers. Rather, the Labour government viewed Sweden and Denmark as models, with free-market liberals focused on the Bismarckian systems, especially Germany.

\section{7-2010: from 'fragmentation' back to the market}

\section{9-2000 the new NHS and the NHS plan}

One of the core planks of Labour's electoral platform in 1997 was a pledge to increase investment in the NHS and reduce waiting times for access to treatment. This was presaged by a two-pronged analysis of its inheritance from the Thatcher and Major Governments. First, that the preceding period had seen serious underfunding of the NHS, and second, that Conservative attempts to implement NPM structures had created fragmentation within the system and worsened, rather than improved outcomes.

This critique of the Conservative-era was set out in The New NHS (Department of Health, 1997), a white paper focused on the 'fragmentation' which the internal market had allegedly introduced. This was contrasted with Labour's plan to introduce a program of 'integrated care'. Nonetheless, Labour retained the purchaser-provider split characteristic of the internal market, though in 1997 it was not envisaged that this would operate competitively or with private providers. Moreover, there was a strong emphasis on decentralisation, regionalism and collaboration, with the white paper repeatedly emphasising cooperation and partnership (Department of Health, 1997: secs. 3.16-3.21, 1.22, 1.3).

Alan Milburn replaced Frank Dobson as Health Secretary in 1999 and continued in the role until 2003. His stewardship of the NHS set the direction for Labour's health policy until it left office in 2010, beginning with 
The NHS Plan (2000). Mirroring some elements of The New NHS, The NHS Plan was also critical of the internal market and was highly critical of the perceived 'lottery in provision' it had created. A general taxation-funded model was articulated as the best way to control this tendency for 'fragmentation' in markets. To support this, The NHS Plan (2000: 36) argued that tax-financed systems (e.g., British and Nordic) were the least socially regressive of the various options due to their interpersonal redistributive capacity. SHI systems (e.g., German and Dutch) were considered slightly more regressive, and private insurance systems (e.g., the US and Swiss), the most regressive. The NHS, and by implication the Nordic systems, was defended in terms of their progressive and equal character in contrast to the SHI systems used in continental Europe. Milburn (2000) deployed similar ideas in speeches.

However, criticism of the internal market in The NHS Plan is significantly more circumspect than in The New NHS. Although the former ostensibly offered a muscular critique of the Thatcher and Major records in healthcare, it is critical not of quasi-markets per se, instead arguing that the internal market was a 'false market'. The NHS Plan demonstrated a move back towards the logic of 'choice', although not competition, and it reflected ambiguity in New Labour's thinking about the relationship between 'equality' and 'choice' as political goals (see, e.g., Tony Blair's (1997) letter to Isaiah Berlin).

Around 2000, then, there was a notable shift in the approach to NPM structures in the UK government. In the period from 1997 to 1999, the reform trajectory moved away from markets in the health service and towards coordination and collaboration. From 2000, that emphasis reversed. This was also a period when ideas about the nature of healthcare reform which would later become strongly associated with the Nordic countries began to develop. Labour argued that its reforms would create a 'leaner and more focused centre' (Department of Health, 2000: 56); although not explicitly mentioned, this clearly echoed trends for the adoption of 'lean management' techniques in Swedish healthcare (The Economist, 2002).

\section{0-2003 return to the market}

Models of Danish and Swedish healthcare appeared in government white papers for the first time in Delivering the NHS Plan (Department of Health, 2002). The white paper noted the charge that 'a tax funded national system of health care can never deliver choice for patients'. It continued: '[I] $\mathrm{n}$ Sweden and Denmark patients have access to information on waiting for treatment have the choice of an alternative provider' (Department of Health, 2002: 22). Despite fairly major structural differences between Swedish and Danish healthcare models, the innovation here was threefold. First, the patient was situated as a consumer within a system of potential choices and providers; second, this movement was presented as possible within a 
tax-funded healthcare system and third, Nordic healthcare models were deployed to legitimate the preceding claims.

The appearance of Nordic policy models in government white papers coincided with growing interest in the popular press as well as increased pressure to introduce 'choice' measures in the NHS. An article in The Times argued that the Danish and Swedish models of healthcare placed 'an enormous weight on empowering doctors and individual patients' despite their taxation funded systems (Hawkes, 2002). The Guardian and Independent also ran pieces praising aspects of the Nordic healthcare systems, especially the introduction of market (dis)incentives for providers to reduce common issues like 'bed blocking' (Charter, 2002a; Dean, 2002; Laurance, 2002).

The Conservative opposition also deployed Nordic examples, with Liam Fox, the Shadow Health Secretary, criticising Labour's reforms for 'borrowing the language of ... Sweden ... but not the substance' by not introducing a deeper purchaser-provider split in the NHS (Charter, 2002b). Free-market policymakers were arguing simultaneously for the intensification of market reforms along Swedish lines, including allowing NHS bodies to borrow commercially, as well as taking Germany's SHI system as a source of inspiration (Charter, 2002b; Ivens, 2002).

Free-market policy think tanks, especially the CPS, and the business press, particularly The Economist, focused on the expansion of market mechanisms, noting that Sweden had several for-profit providers operating hospitals and expounding measures which displayed striking similarities to those which had been introduced in Sweden (Blackwell, 2001; Blackwell and Kruger, 2002). Alongside this, there was significant discussion of the entrance of private providers into the NHS.

This discussion of private provision was often couched in terms of a 'Swedish model of healthcare' or the 'Stockholm model' of private care (Gillan, 2001; Waples, 2001; Wright and Crisp, 2002; The Economist, 2002). The Stockholm Model referred to a model of healthcare in which primary care was privatised though still publicly funded. This entailed the privatisation of several hospitals in Stockholm county and a system of 'payment by results', in which hospitals received money for the procedures performed. Articles were particularly focused on St. Göran's Hospital in Stockholm, and it was claimed that the use of private provision had decreased waiting times and improved the quality of care (The Economist, 2002). Notably, the Swedish ideological dividing line mirrored the British one, with the Moderates controlling Stockholm council and introducing privatisation measures which the Social Democratic-led national government opposed.

By 2003, the coordinates of New Labour's direction in healthcare policy and the political discourses around which it aimed to defend these were already relatively well established. Swedish and Danish healthcare had been widely cited in the press as models of taxation-funded care which could also satisfy concerns about patient choice. From the perspective of the Labour government, the use of Nordic models allowed it to argue in favour of 
patient choice and legitimate the potential for choice measures in a taxation funded system with reference to concrete healthcare systems in Sweden and Denmark.

Given that the major policy creation phase was effectively over by 2002, the difficulty from 2003 onwards was the need to defend the use of markets and the entrance of private company from two directions simultaneously. On the one hand, liberal critics argued that policy had not gone far enough towards introducing markets and private provision in healthcare. On the other hand, left-wing Labour MPs, members and trade unions argued against the introduction of markets and private providers of any sort. In the early 2000s, a discourse was already emerging which argued that New Labour's health reforms were not Swedish enough, with calls for the entrance of private firms and/or the abolition of taxation funded healthcare altogether. The dilemma facing Labour politicians is well encapsulated by this extract from Milburn's (2003) Speech on Localism:

The Right - in the media and in politics - believe the game's up for services that are collectively funded and provided. In today's consumer world they argue that the only way to get services that are responsive to individual needs is through the market mechanism of patients paying for their treatment.

It is easy to dismiss the Right's policies as the last twitch of the Thatcherite corpse. But if we fail to match high and sustained investment with real and radical reform it will be the Centre-Left's argument that public services can both be modern and fair, consumer-orientated, and collectively provided that will face extinction.

Milburn was proved prescient in that from 2003 onwards policy interventions from free-market policymakers adopted positions on healthcare reform which increasingly emphasised the marketisation and privatisation aspects of NPM. Indeed, government policy came under repeated attack from free-market groups hoping to undermine the principle of taxation-funded care. A series of papers published by CPS and two articles in The Daily Telegraph, a conservative newspaper, were considered sufficiently threatening as to warrant a response from John Reid, who took over the health brief in 2003 (Blackwell, 2001; Blackwell and Kruger, 2002; Brogan, 2003; Daley, 2003; Reid, 2003a).

\section{4-2010 defending the benefits of New Public Management}

By 2004, the ideological portion of the reforming phase in New Labour's healthcare policy was effectively over, though this era saw the implementation of new systems as well as the controversial extension of privatisation and marketisation. In this period, private health care providers began to undertake some elective procedures in the NHS. Of note was the entrance 
of the Swedish for-profit healthcare provider Capio which began offering healthcare services as part of joint bids with British providers (as did comparable North American firms) (The Economist, 2004).

The entrance of private providers was often linked back to ideas about the Stockholm model but dovetailed with discussions that would become increasingly entrenched that imagined the role of the state as a funder and regulator rather than a provider of services. This was justified using arguments about the progressive nature of patient choice, whether this was realised in the public or private sector. John Reid, for example, argued that such measures empowered patients noting that: 'empowering patients is directly linked to the issues of inequity. Only if we empower all patients can we realistically aim for the goal of equity' (Reid, 2003b). The definition of equality used here is, therefore, strikingly similar to that deployed by New Public Management theorists since Reid argues that choice - 'underpinned by the resources, the information and power' - is the route to equality.

The presentation of Labour's healthcare measures as progressive and associated with Nordic models which began under Alan Milburn was most explicitly continued by Patricia Hewitt as Health Secretary (2005-2007). Hewitt made use of a Swedish Social Democratic slogan of the time 'proud, but not satisfied' (Hewitt, 2006). It is ironic that in Sweden this slogan was received as a sign of the Social Democrats' lack of ideas and a compelling future vision, which arguably contributed to their loss in the 2006 Swedish General Election (Andersson, 2009a). It is also interesting to note that while Hewitt was committed to competition and marketisation and associated this with Nordic healthcare models, the elements of reform which she most strongly associated with the Nordic countries were not competitive or marketising in nature.

By the mid-2000s, Labour wanted to imitate three chief aspects of the Nordic healthcare models: first, the use of GPs as gatekeepers to the wider system to reduce pressure on hospitals; second, the creation of 'activation' systems which would deal with chronic health conditions allowing people to re-enter the labour market and third, the expansion of community orientated care which reduced the length of hospital stays (Hewitt, 2005, 2007). While these are basically consistent with the goals of Nordic health policy in the mid-2000s, they do not necessarily entail any accompanying extension of markets or private provision.

\section{Nordic localism and health insurance}

From 2004 to 2010, there was a significant change in the focus of policy learning among UK policymakers. This era saw a growing interest in localism and decentralisation in Swedish and Danish healthcare. Though decentralisation was not necessarily associated primarily with marketisation reforms by UK policy thinkers, they were still often a key part of these discourses. Jenkins (2004), for example, viewed Nordic health systems as 
examples of localised systems with greater democratic oversight than the more centralised NHS.

Unlike more free-market-oriented authors, Jenkins was not primarily interested in localisation as a vehicle for NPM reforms, though he acknowledged the potential for this and the title of his report - Big Bang Localism - is a tribute to Margaret Thatcher's deregulation of the City of London. Rather, Jenkins saw the Nordic countries as models in which politics and public policy were democratically accountable with institutions at the local level which entrenched democratic forms of governance. The Nordic countries, he argued, had 'shown that even the smallest communities can run a successful and equitable welfare state' (Jenkins, 2004: 106). This he contrasted negatively with the centralising and managerial tendencies of British politics.

The rolling back of the central state did though tend to entail plans for the extension of the marketisation elements of New Public Management and fiscal retrenchment as a result of the 2008 financial crisis. This partly reflected a growing sense of purpose in the Conservative Party under the leadership of David Cameron. Increasingly, therefore, think-tank and media policy diffusion strategies were targeted at the Conservative Party leadership as well as towards New Labour.

Furness and Gough (2009) echo New Labour's discourse of a progressive Nordic model, contrasted with SHI systems which encounter redistributive limits. Their report, From Feast to Famine, saw Norway and Sweden as models in this respect. They were particularly impressed by decentralised healthcare funding models, arguing that local diversity, funded by locally raised taxes, was a potential model for solving perceived issues in the NHS. The report also argued that any adoption of a more localist, Nordic-style healthcare reform would entail the retreat of the state from mass service provision and its replacement with a range of private (including non-profit) provision. This would entail a total split between purchaser and provider and would, for this reason, mimic the structure of SHI in almost every respect save revenue raising.

The report does though draw a contrast with New Labour's discourse on the Nordic healthcare systems when it notes that:

Evidence from Finland, Norway and Denmark shows that local control over health sector decision-making has led to increased disparities in services provided, and it has been those individuals from lower socio-economic groups who have been adversely affected.

(Furness and Gough, 2009: 140)

New Labour had typically argued that the Nordic systems were successful in reconciling individual freedom with equality. Furness and Gough, perhaps more realistically, argue that policymakers are confronted by a political choice. 
Bidgood's (2013) Healthcare Systems: Sweden and Localism made similar arguments to those found in From Feast to Famine. Bidgood was more concerned to argue for the compatibility of localism and markets in the Swedish system. Although pessimistic about the required culture shift in British politics required for the creation of greater localism, he was positive about the potential for the introduction of further New Public Management ideas by this means. Indeed, demonstrating the tendency for policy actors to be mutually influencing, many of the ideas cited in Bidgood's report, especially those about Capio and lean management, are from articles in The Economist and The Guardian cited above.

By 2013, then, the Nordic systems were no longer seen primarily as a means to defend general taxation-funded healthcare but as a model for a mixture of localism, competition and choice in a system in which private, not-for-profit and public providers competed for public funding. The presentation of Swedish policies as providing space for not-for-profit providers was characteristic of UK policy discussion in this era. It was also a feature of discussion of Swedish Free Schools (Conservatives.com, 2010), though in both cases this was a case of selective policy learning since not-for-profit health and education providers were notably weaker than public or private providers in Sweden (as they are in the United Kingdom) (Andersson, 2006; Wiborg, 2015).

Alongside this was a more empowered and active contingent arguing in favour of Bismarckian insurance-funded healthcare in the United Kingdom. A range of policy reports had put forward arguments in favour of health insurance throughout the New Labour era, but by the late 2000s also had the opportunity to put this to a rejuvenated Conservative Party. Gubb and Meller-Herbert's (2009) Markets in Healthcare restated the case for health insurance using the kind of market logics previously put forward by Blackwell (2001, 2004) and Blackwell and Kruger (2002). These thinkers typically drew on Hayekian ideas about the accountability of markets and sometimes also had positive things to say about the ability of the Nordic systems as well as continental healthcare to imitate markets:

Possibly the most restrictive use of markets is in the NHS in England where the government largely controls the funding, provision, resource allocation and regulation of health care. The market, instead is 'mimicked' through a split between organisations that purchase care and those that provide it .... Interestingly, Nordic countries such as Sweden and Denmark have followed a similar path, although the major difference here is that funds are largely raised through local taxes and health care is the responsibility of local authorities.

(Gubb and Meller-Herbert, 2009: 47)

Very similar arguments in favour of movement towards a Bismarckian healthcare model appeared in Kristian Niemetz's (2014) Health Check 
released through the IEA. This working paper set out a series of practical steps which would alter the current infrastructure of the NHS to make it more closely resemble a SHI system. This included provisions for hospitals to fail, payment by results and other ideas common to free-market arguments about healthcare, removing the functional difference between public and private providers.

Within these discourses, the NHS was contrasted negatively with European systems on a number of counts. Its corporate structure with an artificial quasi-market did not possess the democratic mandate of the Nordic countries; did not allow choice of purchaser, as in Germany, the Netherlands and Switzerland and did not link customer and insurer directly through financial transfer as in the French system.

These pieces reflect the balance of discourse in British health policy in the 2000s. All influential positions argued in favour of marketisation whether through the introduction of NPM, including greater localism or through the introduction of (social) insurance. In both cases, 'choice' for the consumer was privileged over attempts to provide standardised outcomes, which later discourse, in contrast to New Labour politicians, even began to argue was impossible, whether on theoretical grounds (the nature of the market) or empirical ones (fiscal retrenchment).

\section{Conclusion}

Although New Labour's policy record was criticised after the 2008 global financial crisis, there is no questioning the party's political savvy. Developments and trends in healthcare policy in the period following the establishment of the Conservative-Liberal Democrat coalition show that Labour was correct to be concerned about the potential for an organised group to emerge in health policymaking favouring a move towards a SHI system and/ or far more extensive marketisation and privatisation of UK healthcare.

On the other hand, Labour's adoption of a Nordic model, heavily associated with New Public Management ideas, allowed free-market liberals associated with the Conservative Party to pick up where Labour had left off and had the additional consequence of establishing the Nordic model, which in British policy discourses was presented as highly marketising, as the leftmost option in political terms. This opened space for the articulation of more strident SHI options usually based on the German system, as well as localist discourses principally focusing on Sweden which argued for a further intensification of New Public Management in the health service.

Nonetheless, the reform trajectory in the United Kingdom closely approximates these two categories with an immediate shift away from competition and markets and an emphasis on collaboration and partnership upon Labour's assumption of office. This was gradually replaced by a turn back towards ideas more traditionally associated with NPM from 1999 onwards which would intensify in 2002 and 2003. 
From the early 2000s onwards, British Labour politicians had adopted what could best be described as a defensive discourse which propagated particular ideas about a Nordic model in healthcare and its use of NPM principles. Their purpose was to persuade those in favour of greater marketisation and choice that this could be achieved within the framework of a general taxation-funded healthcare system. For this reason, the Nordic countries were the only available choice (other than the United Kingdom itself) for making these arguments.

The 'Nordic' components of New Labour's health programme taken together are an odd mixture of New Public Management, localising ideas and proposed changes to the process of GP referrals as well as elements that simply reflect system convergence in European health systems. Labour politicians themselves though were concerned to link their policies to precedent set by the taxation-funded Nordic countries as a defence against criticism from free-market liberals on the one hand and Labour's left on the other hand.

The (co-)creation and circulation of Nordic models in British healthcare in the late 1990s and 2000s represent something of a paradox. New Labour's utterances about the Nordic countries were relatively accurate and often based on specific policies, even where these policies were not necessarily consistent with Labour's agenda. For example, in the mid-2000s, Nordic policies demonstrated a collaborative turn where UK policymakers favoured competition. Labour did though tend to downplay those aspects of Nordic policies which did not fit their preconceived agenda while emphasising facets such as privatisation, marketisation, decentralisation, which were consistent with the policies they hoped to enact in Britain. In this process of translation, then, Nordic policies tended to be seen primarily in terms of their consistency with propositions about localism and marketisation. There was nonetheless a clear political preference for Nordic or Scandinavian models in British healthcare discourse, even where Nordic policies and ideas were presented as highly marketising.

It is, therefore, relevant to question to what extent these policies were actually Nordic or European, and, despite the widespread and sometimes haphazard use of models taken from Scandinavia, what they added to British public policy debate. It is tempting to argue that the use of these models offered legitimacy to policy proposals, but as the so-called 'Norway model of Brexit' demonstrates, models can mystify as readily as they clarify. Moreover, there is very little evidence to suggest that Nordic or European actors, with the exception of some private healthcare firms such as Capio, were engaged in propagating these discourses in the United Kingdom. What emerges from the analysis is a policy learning process in the United Kingdom which is reliant on exemplars imported from elsewhere, but simultaneously closed, insular and concerned primarily with internal political debates rather than the substance of policies which are increasingly central to the policymaking process. 
The UK policy learning process observed here, therefore, reflects a very British form of diffusion. Since 2010, the Conservatives have made virtually no use of foreign healthcare models, but, if anything, the process of deriving legitimacy from 'policy learning' has intensified. Perhaps the most obvious Nordic example of this is the adoption of Free Schools, based on a Swedish marketising reform from the early 1990s (Rönnberg, 2015). This has also been observable in debates about the United Kingdom's relationship with the European Union with a whole host of possible models suggested, including Norway, Canada, Australia and various others.

This chapter has contributed to the literature examining policy diffusion and the circulation of Nordic models. The study of policy diffusion in the United Kingdom and the use of policy models is, in many respects, an urgent one since international policy models have been so central to a highly politically and economically controversial Brexit process. Moreover, from a Nordic perspective, it is notable that the Nordic model, in various guises, has now been taken up very widely as a policy model on the British Right and is increasingly less associated with the Labour Party, which would, historically at least, have seemed a more natural site of mutual policy diffusion.

This interest in Norden among Conservative politicians is a potential future avenue for research on the making and circulation of Nordic models. This chapter has adopted a qualitative approach to the question of policy diffusion, allowing for a more detailed assessment of the articulations of Nordic policy than a quantitative approach would have, but at the same time limiting the scope of material that could be covered. Future research on these questions, especially those taking up issues such as the 'Norway model of Brexit', may well wish to adopt quantitative or content analysis approaches to these questions to deal with the vast amount of literature which was produced on the subject, especially in the popular press, but also in think tanks, political speeches and by legal experts.

\section{References}

Aimer, P. (1985), 'The Strategy of Gradualism and the Swedish Wage-Earner Funds', West European Politics, 8(3), 43-55.

Anderson, P. (1961a), 'Mr Crosland's Dreamland', New Left Review, 1(7), 4-12.

Anderson, P. (1961b), 'Sweden: Study in Social Democracy', New Left Review, 1(9), 34-45.

Andersson, J. (2009a), När Framtiden Redan Hänt: Socialdemokratin och folkhemsnostalgin (Stockholm: Ordfront).

Andersson, J. (2009b), 'Nordic Nostalgia and Nordic Light: The Swedish Model as Utopia 1930-2007', Scandinavian Journal of History, 34(3), 229-245.

Andersson, J. (2010), The Library and the Workshop: Social Democracy in the Knowledge Age (Stanford, CA: Stanford University Press).

Andersson, M. (2006), Liberalisation, Privatisation and Regulation in the Swedish Healthcare Sector/Hospitals (Göteborg: Department of Work Science, Göteborg University), 1-33. 
Ball, S. and S. Exley (2010), 'Making Policy with "Good Ideas": Policy Networks and the "Intellectuals" of New Labour', Journal of Education Policy, 25(2), 151-169.

Bidgood, E. (2013), Healthcare Systems: Sweden \& Localism - An Example for the UK? (London: Civitas).

Bjurstrøm, K. H. and T. Christensen (2017), 'Government Institutions and State Reforms', in O. Knutsen (ed.), The Nordic Models in Political Science: Challenged, but Still Viable? (Bergen: Fagbokforlaget), 149-170.

Blackwell, N. (2001), Towards Smaller Government (London: Centre for Policy Studies).

Blackwell, N. (2004), Better Schools and Hospitals (London: Centre for Policy Studies).

Blackwell, N. and D. Kruger (2002), Better Healthcare for All (London: Centre for Policy Studies).

Blair, T. (1997), 'A Letter from Tony Blair', available at: http://berlin.wolf.ox.ac.uk/ letterstoberlin.html.

Blomgren, M. and K. Sahlin (2007), 'Quests for Transparency: Signs of a New Institutional Era in the Health Care Field', in T. Christensen and P. Lægreid (eds.), Transcending New Public Management: The Transformation of Public Sector Reforms (Aldershot: Ashgate), 155-177.

Brogan, B. (2003), 'Voters Would Buy Health Insurance If Tax Is Cut', The Daily Telegraph, July 14.

Brown, W. (2015), Undoing the Demos: Neoliberalism's Stealth Revolution (Brooklyn, NY: Zone Books).

Byrkjeflot, H. and S. Neby (2008), 'The End of the Decentralised Model of Healthcare Governance? Comparing Developments in the Scandinavian Hospital Sectors', Journal of Health Organization and Management, 22(4), 331-349.

Charter, D. (2002a), 'Milburn Acts to Ease Bed Blocking', The Times, March 14.

Charter, D. (2002b), 'Tories Inspired by German Health Service', The Times, July 10.

Christensen, T. and P. Lægreid (2002), 'New Public Management - Undermining Political Control', in T. Christensen and P. Lægreid (eds.), Transcending New Public Management: The Transformation of Public Sector Reforms (Aldershot: Ashgate), 93-120.

Christensen, T. and P. Lægreid (2007), 'Introduction - Theoretical Approach and Research Questions', in T. Christensen and P. Lægreid (eds.), Transcending New Public Management: The Transformation of Public Sector Reforms (Aldershot: Ashgate), 1-17.

Christensen, T., A. Lie and P. Lægreid (2007), 'Still Fragmented Government or Reassertion of the Centre', in T. Christensen and P. Lægreid (eds.), Transceding New Public Management: The Transformation of Public Sector Reforms (Aldershot: Ashgate), 18-41.

Conservatives.com (2010), The Conservative Manifesto. DOI: 10.1016/j. ijnurstu.2005.07.001.

Crosland, C. A. R. (1980), The Future of Socialism (London: Jonathan Cape).

Daley, J. (2003), 'The New Britain Wants More Choice', The Daily Telegraph, July 16.

Dean, M. (2002), 'Society: Any Chance of NHS Choice', The Guardian, April 24.

Department of Health (1997), The New NHS (London: Department of Health).

Department of Health (2000), The NHS Plan (London: Department of Health). 
Department of Health (2002), 'Delivering the NHS Plan: Next Steps on Investment Next Steps on Reform', Department of Health, April.

Einhorn, E. S. and J. Logue (2003), Modern Welfare States: Scandinavian Politics and Policy in the Global Age (London: Praeger).

Furness, D. and B. Gough (2009), From Feast to Famine-Reforming the NHS for an Age of Austerity (London: Social Market Foundation).

Gilardi, F. (2010) 'Who Learns from What in Policy Diffusion Processes?', American Journal of Political Science, 54(3), 650-666.

Gillan, A. (2001) 'Election 2001: Public Backing for Sweden's Private Success', The Guardian, May 29.

Greener, I. (2009), 'Towards a History of Choice in UK Health Policy', Sociology of Health and Illness, 31(3), 309-324.

Greener, I. and M. Powell (2008), 'The Changing Governance of the NHS: Reform in a Post-Keynesian Health Service', Human Relations, 61(5), 617-636.

Greenfield, G., K. Foley and A. Majeed (2016), 'Rethinking Primary Care's Gatekeeper Role', British Medical Journal, 354, 1-6.

Greer, S. (2004), Territorial Politics and Health Policy (Manchester: Manchester University Press).

Grossback, L. J., S. Nicholson-Crotty and D. A. M. Peterson (2004), 'Ideology and Learning in Policy Diffusion', American Political Research, 32(5), 521-545.

Gubb, J. and O. Meller-Herbert (2009), Markets in Health Care: The Theory Behind the Policy (London: Civitas).

Hale, F. (2006), 'Brave New World in Sweden? Roland Huntford's "The New Totalitarians", Scandinavian Studies, 78(2), 167-190.

Hale, F. (2009), 'British Observers of the Swedish Welfare State, 1932-1970', Scandinavian Studies, 81(4), 501-528.

Hawkes, N. (2002), 'Theory and Practice', The Times, April 19.

Hewitt,P.(2005), 'UKPresidencyoftheEUSummit:TacklingHealthInequalities', available at http://webarchive.nationalarchives.gov.uk/20130107105354/http://www. dh.gov.uk/en/MediaCentre/Speeches/Speecheslist/DH_4125537 [accessed April 22, 2021]

Hewitt, P. (2006), 'Creating a Patient-Led NHS: The Next Steps Forward', available at http://webarchive.nationalarchives.gov.uk/20130107105354/http://www. dh.gov.uk/en/MediaCentre/Speeches/Speecheslist/DH_4126499 [accessed April 22, 2021]

Hewitt, P. (2007), 'Investment and Reform: Transforming Health and Healthcare', available at http://webarchive.nationalarchives.gov.uk/20130107105354/http://www. dh.gov.uk/en/MediaCentre/Speeches/Speecheslist/DH_4124484 [accessed April 22, 2021]

Hilson, M. and A. Newby (2015), 'The Nordic Welfare Model in Norway and Scotland', in J. Bryden, L. Riddoch and O. Brox (eds.), Northern Neighbours: Scotland and Norway since 1800 (Edinburgh: Edinburgh University Press), 211-229.

Hinrichs, K. (2010), 'A Social Insurance State Withers Away. Welfare State Reforms in Germany - Or: Attempts to Turn Around in a Cul-de-Sac', in B. Palier (ed.), A Long Goodbye to Bismarck? The Politics of Welfare Reform in Continental Europe (Amsterdam: Amsterdam University Press), 45-72.

Huntford, R. (1971), The New Totalitarians (London: Allen Lane).

Ivens, M. (2002), 'Cross Dressing Could Suit the Tories', The Sunday Times, May 26. 
Jackson, B. (2012), 'The Think-Tank Archipelago: Thatcherism and Neo-liberalism', in B. Jackson and R. Saunders (eds.), Making Thatcher's Britain (Cambridge: Cambridge University Press), 43-61.

Jenkins, S. (2004), Big Bang Localism: A Rescue Plan for British Democracy (London: Policy Exchange).

Kettunen, P. (2012), 'Reinterpreting the Historicity of the Nordic Model', Nordic Journal of Working Life Studies, 2(4), 21-43.

Krachler, N. and I. Greer (2015), 'When Does Marketisation Lead to Privatisation? Profit-Making in English Health Services after the 2012 Health and Social Care Act', Social Science and Medicine, 124, 215-223.

Laurance, J. (2002), 'Bed Blocking the Scandinavian Solution', The Independent, April 19.

Logue, J. (1999), 'The Swedish Model: Visions of Sweden in American Politics and Political Science', Swedish-American Historical Quarterly, 50(3), 162-172.

Lyttkens, C. H. et al. (2016), 'The Core of the Nordic Health Care System Is Not Empty', Nordic Journal of Health Economics, 4(1), 7-27.

Maggetti, M. and F. Gilardi (2016), 'Problems (and Solutions) in the Measurement of Policy Diffusion Mechanisms', Journal of Public Policy, 36(1), 87-107.

Magnussen, J. and P. E. Martinussen (2013), 'From Centralization to Decentralization, and Back: Norwegian Health Care in a Nordic Perspective', in J. Costa-Font and S. L. Greer (eds.), Federalism and Decentralization in European Health and Social Care (London: Palgrave Macmillan), 101-123.

Marklund, C. (2009), 'The Social Laboratory, the Middle Way and the Swedish Model : Three Frames for the Image of Sweden', Scandinavian Journal of History, 34(3), 264-285.

Martinussen, P. E. and J. Magnussen (2009), 'Health Care Reform: The Nordic Experience', in J. Magnussen, K. Vrangbæk and R. B. Saltman (eds.), Nordic Health Care Systems (Maidenhead: McGraw-Hill), 21-52.

Milburn, A. (2000), 'The Contribution of a Modern NHS', available at http:// webarchive.nationalarchives.gov.uk/20130107105354/http://www.dh.gov.uk/en/ MediaCentre/Speeches/Speecheslist/DH_4000761 [accessed April 22, 2021]

Milburn, A. (2003), 'Speech on Localism', https://www.ukpol.co.uk/alan-milburn2003-speech-on-localism/

Musial, K. (2000), Roots of the Scandinavian Model: Images of Progress in the Era of Modernisation (Baden-Baden: Nomos Vergesellschaft).

Niemetz, K. (2014), Health Check: The NHS and Market Reforms (London: The Institute of Economic Affairs).

Nuder, P. (2002), 'Challenge of Renewal', in Progressive Politics 1.1, (London: Policy Network), 40-45.

Nuder, P. (2012), Saving the Swedish Model (London: Institute for Public Policy Research).

Olsen, K. R. et al. (2016), 'General Practice in the Nordic countries', Nordic Journal of Health Economics, 4(1), 56-67.

Palier, B. (2010), 'Understanding the "Bismarckian" Welfare Reform Trajectory', in B. Palier (ed.), A Long Goodbye to Bismarck? (Amsterdam: Amsterdam University Press), 18-44.

Palier, B. and C. Martin (2008), 'From "a Frozen Landscape" to Structural Reforms: The Sequential Transformation of Bismarckian Welfare Systems', in Reforming the Bismarckian Welfare Systems (Oxford: Blackwell). 
Reid, J. (2003a), 'Choice Speech to the New Health Network', available at http:// collection.europarchive.org/tna/20040722012352/http://dh.gov.uk/en/News/ Speeches/Speecheslist/DH_4071487 [accessed April 22, 2021]

Reid, J. (2003b), 'Equity, Choice, Capacity and Culture', available at http:// collection.europarchive.org/tna/20040722012352/http://dh.gov.uk/en/News/ Speeches/Speecheslist/DH_4066541 [accessed April 22, 2021]

Rommetvedt, H. (2017), 'Scandinavian Corporatism in Decline', in O. Knutsen (ed.), The Nordic Models in Political Science: Challenged, but Still Viable? (Bergen: Fagbokforlaget), 171-192.

Rönnberg, L. (2015), 'Marketization on Export: Representations of the Swedish Free School Model in English Media', European Educational Research Journal, 14(6), 549-565.

Ryner, J. M. (2002), Capitalist Restructuring, Globalisation and the Third Way: Lessons from the Swedish Model (London: Routledge).

Ryner, J. M. (2007), 'The Nordic Model : Does It Exist? Can It Survive?', New Political Economy, 12(1), 61-70.

Scott, A. (2009). 'Looking to Sweden in Order to Reconstruct Australia', Scandinavian Journal of History, 34(3), 330-352.

Self, P. (1993), Government by the Market? The Politics of Public Choice (London: Macmillan).

Starke, P. (2013), 'Qualitative Methods for the Study of Policy Diffusion: Challenges and Available Solutions', Policy Studies Journal, 41(4), 561-583.

The Economist (2002), 'Stockholm Syndrome', The Economist, February 28.

The Economist (2004), 'Public Money, Private Care', The Economist.

Waples, J. (2001), 'Swede Leads Race for Community Hospitals', The Sunday Times, April 22.

Wennström, J. (2005), The Awful Truth About Sweden (London: Institute of Economic Affairs).

Wiborg, S. (2015), 'Privatizing Education: Free School Policy in Sweden and England', Comparative Education Review, 59(3), 473-497.

Wright, O. and S. Crisp (2002), 'The Chosen Companies', The Times, December 20. 